ISSN: 2302-8556

E-Jurnal Akuntansi Universitas Udayana

Vol.25.2.November (2018): 1534-1564

DOI: https://doi.org/10.24843/EJA.2018.v25.i02.p27

\title{
Pengaruh Profitabilitas dan Solvabilitas pada Ketepatwaktuan Publikasi Laporan Keuangan dengan Ukuran Perusahaan Sebagai Variabel Pemoderasi
}

\author{
I Wayan Winarta ${ }^{1}$ \\ I Nyoman Wijana Asmara Putra ${ }^{2}$
}

${ }^{1}$ Fakultas Ekonomi dan Bisnis Universitas Udayana (Unud), Bali, Indonesia email: iwayan.winarta19@gmail.com / Telp: 083114140019

${ }^{2}$ Fakultas Ekonomi dan Bisnis Universitas Udayana (Unud), Bali, Indonesia

\begin{abstract}
ABSTRAK
Laporan keuangan (financial statement) merupakan salah satu bagian terpenting perusahaan karena memuat informasi tentang posisi keuangan dan kinerja dari suatu perusahaan. Kandungan informasi yang terdapat di dalam laporan keuangan akan bernilai relevan jika dipublikasikan secara tepat waktu. Penelitian ini bertujuan untuk mengetahui pengaruh profitabilitas dan solvabilitas pada ketepatwaktuan publikasi laporan keuangan, dan untuk mengetahui mampu tidaknya ukuran perusahaan memoderasi pengaruh profitabilitas dan solvabilitas pada ketepatwaktuan publikasi laporan keuangan. Jumlah sampel dalam penelitian ini adalah 48 laporan keuangan perusahaan pertambangan yang diperoleh dengan teknik non-probability sampling dengan metode purposive sampling. Teknik analisis yang digunakan dalam penelitian ini adalah Moderated Regression Analysis (MRA). Berdasarkan hasil analisis diketahui bahwa variabel profitabilitas berpengaruh positif pada ketepatwaktuan publikasi laporan keuangan. Sedangkan solvabilitas tidak berpengaruh pada ketepatwaktuan publikasi laporan keuangan. Ukuran perusahaan mampu memperlemah pengaruh profitabilitas pada ketepatwaktuan, tetapi tidak dapat memoderasi pengaruh solvabilitas pada ketepatwaktuan publikasi laporan keuangan.
\end{abstract}

Kata kunci: profitabilitas, solvabilitas, ukuran perusahaan, ketepatwaktuan publikasi laporan keuangan

\begin{abstract}
This study aims to determine the effect of profitability and solvency on the timeliness of the publication of financial statements, and to determine whether or not the size of the company to moderate the effect of profitability and solvency on the timeliness of the publication of financial statements. Samples in this study were 48 mining company financial statements obtained by non-probability sampling technique with purposive sampling method. The analysis technique used in this research is Moderated Regression Analysis. Based on the results of the analysis it is known that the profitability variable has a positive effect on the timeliness of the publication of financial statements. Whereas solvability does not affect the timeliness of the publication of financial statements. The size of the firm is able to weaken the effect of profitability on timeliness, but can not moderate the effect of solvency on the timeliness of the publication of financial statements.
\end{abstract}

Keywords: profitability, solvency, firm size, timeliness of financial report publication. 


\section{PENDAHULUAN}

Pada era globalisasi saat ini, banyak perusahaan publik di Indonesia telah mengalami kemajuaan yang sangat pesat. Perusahaan publik harus mencari cara agar mampu tetap bersaing ditengah-tengah persaingan bisnis. Hal ini menyebabkan konsekuensi dibutuhkannya suatu pendanaan yang lebih besar bagi aktivitas investasi dan operasional perusahaan, agar mampu bertahan dari para pesaingnya. Sumber pendanaan bagi perusahaan dapat diperoleh dari investor dan kreditor, dimana kedua pihak membutuhkan informasi keuangan untuk mengambil keputusan investasi. Pasar modal yang menjadi penghubung antara para investor dengan perusahaan ataupun institusi pemerintah untuk berbagai instrument keuangan jangka panjang yang bisa diperjualbelikan, baik dalam bentuk utang ataupun modal sendiri.

Perkembangan pasar modal saat ini semakin mengalami peningkatan dari waktu ke waktu. Faktor yang mempengaruhi aktivitas investasi dalam pasar modal adalah informasi yang masuk ke pasar modal tersebut. Untuk memenuhi informasi investasi tersebut, maka setiap perusahaan yang go public ataupun yang sudah terdaftar di Bursa Efek Indonesia (BEI) memiliki kewajiban untuk menyampaikan laporan keuangan yang disusun sesuai dengan standar akuntansi keuangan dan telah diaudit tepat waktu.

Laporan keuangan (financial statement) merupakan salah satu bagian terpenting perusahaan karena memuat informasi tentang posisi keuangan dan kinerja dari suatu perusahaan. Tujuan dari laporan keuangan adalah untuk memberikan informasi tentang posisi keuangan, kinerja, dan arus kas yang 
bermanfaat bagi sebagian besar kalangan pengguna laporan dalam rangka membuat keputusan-keputusan ekonomi (Diastiningsih dan Tenaya, 2017). Laporan keuangan yang terdiri atas informasi posisi keuangan, kinerja dan perubahan posisi keuangan suatu perusahaan ini disusun bertujuan untuk memenuhi kebutuhan pemakainya, namun tak jarang laporan keuangan tidak menyediakan informasi yang dibutuhkan pemakai dalam mengambil keputusan ekonomi, yang menjadikan unsur ketepatwaktuan (timeliness) penting dalam penyajian suatu informasi yang relevan. Laporan keuangan juga dapat menunjukkan hasil dari pertanggungjawaban manajemen atas penggunaan sumber daya yang telah dipercayakan kepada mereka. Laporan keuangan memiliki empat karakteristik kualitatif yaitu dapat diperbandingkan (comparability), andal (reliable), relevan (relevance), dan dapat dipahami (understandability.

Ketepatwaktuan (timelines) adalah salah satu aspek penting agar laporan keuangan yang disampaikan menjadi informasi relevan (Clatworthy, 2010). Ketepatwaktuan laporan keuangan yang telah diaudit dan dipublikasikan merupakan salah satu atribut kualitatif penting yang diinginkan dari setiap informasi akuntansi yang baik (Oladipupo dan Izedomi, 2013). Wijayanthi dan Budiartha (2016) menjelaskan bahwa ketepatwaktuan (timeliness) merupakan salah satu faktor penting dalam penyajian laporan keuangan kepada publik sehingga perusahaan diharapkan untuk tidak menunda penyajian laporan keuangannya agar informasi tersebut tidak kehilangan kemampuannya dalam mempengaruhi pengambilan keputusan. Penyampaian laporan keuangan secara 
I Wayan Winarta dan I Nyoman Wijana Asmara Putra. Pengaruh...

tepat waktu akan berpengaruh pada relevansi yang terdapat pada kandungan informasi laporan keuangan tersebut. Kandungan informasi yang terdapat di dalam laporan keuangan akan bernilai relevan jika dipublikasikan secara tepat waktu. Begitu juga sebaliknya, jika laporan keuangan dipublikasikan tidak tepat waktu atau terlambat, maka nilai kandungan informasi tersebut menjadi berkurang.

Tuntutan akan kepatuhan terhadap ketepatwaktuan publikasi laporan keuangan perusahaan publik di Indonesia telah diatur dalam Peraturan Bapepam yang saat ini sudah melebur dalam Lembaga Otoritas Jasa Keuangan (OJK) pada tahun 2012 yakni Surat Keputusan Ketua Badan Pengawas Pasar Modal dan Lembaga Keuangan Nomor Kep-431/BL/2012, Peraturan Bapepam Nomor X.K.6 yang menyatakan bahwa laporan keuangan tahunan wajib disampaikan kepada Bapepam dan LK dan diumumkan kepada masyarakat paling lambat pada akhir bulan keempat setelah tanggal laporan keuangan tahunan. Perusahaan yang terlambat menyampaikan laporan keuangan, akan dikenakan sanksi administratif sesuai dengan ketentuan yang telah ditetapkan.

Meskipun peraturan tentang penyampaian laporan keuangan sudah ditetapkan, kenyataannya masih ada beberapa emiten yang terlambat mempublikasikan laporan keuangannya. Berdasarkan wartaekonomi.co.id, BEI mengemukakan jumlah emiten yang belum menyampaikan laporan keuangan adalah sebesar 52 emiten yang belum menyampaikan laporan keuangan audit per Desember 2014 (neraca.co.id). Namun trend keterlambatan penyampaian 
ISSN: 2302-8556

E-Jurnal Akuntansi Universitas Udayana

Vol.25.2.November (2018): 1534-1564

laporan keuangan mengalami penurunan, di mana BEI mencatat ada 18 emiten belum menyampaikan laporan keuangan audit per 31 Desember 2015 (cnnindonesia.com). Kemudian menurut finance.detik.com, terdapat 17 perusahaan tercatat yang belum menyampaikan laporan keuangan audit per 31 Desember 2016.

Isu terkait ketepatwaktuan publikasi laporan keuangan ini sebenarnya telah banyak diteliti sebelumnya. Hasil dari penelitian sebelumnya mengungkapkan bahwa beberapa faktor dapat mempengaruhi ketepatwaktuan publikasi laporan keuangan. Profitabilitas merupakan salah satu indikator keberhasilan perusahaan untuk dapat menghasilkan laba pada masa mendatang, sehingga semakin tinggi profitabilitas maka semakin tinggi kemampuan perusahaan untuk menghasilkan laba bagi perusahaannya (Sanjaya dan Wirawati, 2016). Sebuah perusahaan dapat memperoleh keuntungan atau mereka dapat membuat kerugian, tergantung pada faktor politik dan ekonomi (Adebayo dan Adebiyi 2016). Tingkat kemampuan perusahaan dalam mengahasilkan keuntungan yang dilaporkan diperkirakan dapat mempengaruhi tepat atau tidaknya waktu penyajian laporan keuangan kepada publik. Penelitian yang dilakukan oleh Hasniar dan Widyatmini (2012), menyatakan bahwa ketika perusahaan memiliki tingkat profitabilitas yang tinggi maka perusahaan cenderung melakukan publikasi laporan keuangannya secara tepat waktu, sebaliknya saat tingkat profitabilitas terlalu rendah maka hal tersebut dapat menyebabkan perusahaan terlambat dalam melakukan publikasi laporan keuangan. Hal serupa disampaikan Mahendra dan Putra, 2014 bahwa perusahaan 
I Wayan Winarta dan I Nyoman Wijana Asmara Putra. Pengaruh...

yang memperoleh laba, cenderung tepat waktu menyampaikan laporan keuangannya, dan begitu pula sebaliknya. Perusahaan atau emiten akan menunda penyampaian laporan keuangan jika terjadi adanya berita buruk (bad news) yang menyangkut kualitas laba perusahaan.

Penelitian terdahulu memiliki hasil yang berbeda-beda tentang pengaruh profitabilitas terhadap ketepatwaktuan publikasi laporan keuangan. Menurut Mahendra dan Putra, (2014) menyatakan bahwa profitabilitas berpengaruh positif terhadap ketepatwaktuan publikasi laporan keuangan tahunan. Hal ini didukung oleh Putra dan Ramantha, (2015) yang menyatakan bahwa profitabilitas berpengaruh positif terhadap ketepatwaktuan publikasi laporan keuangan. Hasil sebaliknya disimpulkan oleh Khasharmeh dan Aljifri (2010) serta Putri dan Putra (2018), yang menyatakan bahwa profitabilitas tidak berpengaruh pada ketepatwaktuan publikasi laporan keuangan tahunan, serta menurut Joened dan Damayanthi (2016), menyatakan bahwa profitabilitas berpengaruh negatif pada ketepatwaktuan pelaporan keuangan.

Faktor solvabilitas juga dikatakan sebagai salah satu faktor yang berpengaruh terhadap ketepatwaktuan publikasi laporan keuangan. Solvabilitas merupakan kemampuan perusahaan untuk memenuhi kewajiban finansialnnya baik dalam jangka pendek maupun jangka panjang, atau mengukur sejauh mana perusahaan dibiayai dengan utang (Wiagustini, 2014:85). Semakin tinggi laverage keuangan maka perusahaan tersebut memiliki banyak utang pada pihak luar sehingga resiko keuangan semakin tinggi karena mengalami kesulitan keuangan. 
Almilia dan Setiady, 2006 menjelaskan bahwa solvabilitas yang buruk akan mengindikasikan bad news bagi perusahaan karena akan menunjukan adanya risiko keuangan yang tinggi akibat kesulitan dalam membayar utang yang besar. Beberapa penelitian terdahulu memiliki hasil yang berbeda-beda tentang pengaruh solvabilitas pada ketepatwaktuan publikasi laporan keuangan. Menurut Dewi dan Pamudji, 2013, dan Devi dan Suaryana, 2016 menyimpulkan bahwa solvabilitas tidak memiliki pengaruh terhadap ketepatan waktu penyampaian laporan keuangan. Sedangkan penelitian Pande dan Mertha, 2016 menyatakan bahwa solvabilitas berpengaruh positif terhadap keterlambatan penyampaian laporan keuangan, hal ini berarti solvabilitas berpengaruh negatif terhadap ketepatwaktuan publikasi laporan keuangan.

Beberapa penelitian terdahulu yang menguji tentang ketepatwaktuan publikasi laporan keuangan ke publik dengan faktor-faktor yang mempengaruhinya memiliki hasil dan pendapat yang berbeda-beda. Oleh karena itu peneliti ingin mengujinya kembali hubungan profitabilitas dan solvabilitas pada ketepatwaktuan publikasi laporan keuangan dan menggunakan variabel moderasi yaitu ukuran perusahaan. Ukuran perusahaan diukur berdasarkan besar atau kecilnya perusahaandengan melihat total aset atau total penjualan yang dimiliki oleh perusahaan (Mahendra dan Putra, 2014). Ukuran perusahaan dihitung dengan log total aset, semakin besar aset yang dimiliki perusahaan maka semakin besar juga ukuran perusahaannya. Ukuran perusahaan dapat menunjukan seberapa besar informasi yang terdapat di dalamnya, sekaligus mencerminkan 
kesadaran dari pihak manajemen mengenai pentingnya informasi, baik bagi pihak internal maupun eksternal perusahaan (Almilia dan Setiady, 2006). Perusahaan yang berukuran lebih besar cenderung lebih cepat dalam publikasi laporan keuangannya daripada perusahaan kecil (Atiase, 1989). Penetapan ukuran perusahaan sebagai variabel pemoderasi dalam penelitian ini karena dianggap mampu memperkuat atau memperlemah pengaruh profitabilitas dan solvabilitas pada ketepatwaktuan publikasi laporan keuangan.

Perusahaan pertambangan dipilih sebagai sampel penelitian didasarkan pada beberapa pertimbangan. Pertama, karena perusahaan sektor pertambangan memegang peranan penting dalam mendukung perekonomian Indonesia. Kedua, berdasarkan data yang terdapat dalam website www.idx.co.id menunjukkan bahwa pengawasan ketat oleh pihak-pihak tertentu terhadap perusahaan pertambangan tidak menjamin bahwa perusahaan tepat waktu mempublikasikan laporan tahunan, sehingga masih terdapat perusahaan sektor pertambangan yang terlambat mempublikasikan laporan tahunan. Penelitian ini didukung dengan fenomena yang terjadi pada perusahaan tambang batubara milik Grup Bakrie, PT Bumi Resources Tbk (BUMI) menyatakan belum bisa mengeluarkan laporan keuangan tahunan 2014 karena perseroan masih berjibaku dengan perhitungan utang.

Tujuan penelitian ini yaitu: 1) Untuk menguji secara empiris pengaruh profitabilitas pada ketepatwaktuan publikasi laporan keuangan; 2) Untuk menguji secara empiris pengaruh solvabilitas pada ketepatwaktuan publikasi laporan keuangan; 3) Untuk memperoleh bukti ukuran perusahaan memoderasi pengaruh 
ISSN: 2302-8556

E-Jurnal Akuntansi Universitas Udayana

Vol.25.2.November (2018): 1534-1564

profitabilitas pada ketepatwaktuan publikasi laporan keuangan; 4) Untuk memperoleh bukti ukuran perusahaan memoderasi solvabilitas pada ketepatwaktuan publikasi laporan keuangan.

Hasil penelitian dapat menambah wawasan pembaca tentang pengaruh profitabilitas, dan solvabilitas pada ketepatwaktuan publikasi laporan keuangan dengan ukuran perusahaan sebagai pemoderasi, yang dihubungkan dengan pengetahuan teoritis, khususnya teori-teori yang berkaitan dengan praktik ketepatwaktuan publikasi laporan keuangan yaitu ketepatwaktuan publikasi laporan keuangan dan teori sinyal serta ketepatwaktuan publikasi laporan keuangan dan teori kepatuhan. Penelitian ini juga bertujuan untuk mendukung temuan-temuan riset sebelumnya dan dapat dijadikan referensi untuk penelitian selanjutnya.

Teori yang mendukung penelitian ini adalah teori sinyal (Signaling Theory). Setiap perusahaan go public diwajibkan untuk mempublikasikan laporan keuangan yang berisi mengenai semua informasi keuangan dan non keuangan yang mencerminkan kinerja perusahaan. Kualitas suatu informasi harus bersifat akurat, lengkap, dan tepat waktu, karena nantinya akan menjadi suatu sinyal bagi investor dalam mengambil suatu keputusan bisnis. Semakin baik kualitas informasi yang disajikan maka semakin baik pula kualitas keputusan investor. Sinyal biasanya berisi mengenai informasi yang mengandung unsur penting bagi investor, diantaranya gambaran mengenai keadaan perusahaan, catatan masa lalu maupun keadaan yang akan datang mengenai kelangsungan hidup perusahaan. 
Ayushabrina (2014) menyatakan bahwa teori sinyal juga bermanfaat dalam menjelaskan ketepatwaktuan (sifat relevan) penyajian laporan keuangan tahunan yang telah diaudit kepada pihak publik sehingga dapat memberi sinyal bahwa perusahaan mempunyai informasi yang bermanfaat atau memiliki good news. Bagi investor, ketepatwaktuan dalam mempublikasikan laporan keuangan ke publik dinilai sebagai sinyal positif dari perusahaan yang mana berarti perusahaan memiliki good news yang harus disampaikan ke publik, begitu juga sebaliknya. Perusahaan yang mengalami rugi (profitabilitas rendah) kemungkinan terjadinya kecurangan manajemen mengenai informasi laba (Carslaw dan Kaplan, 1991). Begitu juga dengan perusahaan yang mengalami kesulitan keuangan dimana manajemen melakukan penundaan pelaporan hutang, karena hal tersebut merupakan berita buruk (bad news) bagi perusahaan.

Kepatuhan berasal dari kata patuh, yang menurut Kamus Besar Bahasa Indonesia, patuh berarti suka menurut perintah, taat kepada perintah atau aturan dan berdisiplin. Kepatuhan berarti bersifat patuh, ketaatan, tunduk, patuh pada ajaran dan aturan. Teori kepatuhan telah diteliti pada ilmu-ilmu sosial khususnya di bidang psikologis dan sosiologis yang lebih menekankan pada pentingnya proses sosialisasi dalam mempengaruhi perilaku kepatuhan seorang individu (Saleh dan Susilowati, 2004). Tuntutan akan kepatuhan terhadap waktu penyampaian laporan keuangan berkala oleh perusahaan publik kepada Bapepam di Indonesia telah diatur dalam Undang-Undang No. 8 tahun 1995 tentang Pasar 
ISSN: 2302-8556

E-Jurnal Akuntansi Universitas Udayana

Vol.25.2.November (2018): 1534-1564

Modal, dan selanjutnya diatur dalam Peraturan Bapepam tentang Kewajiban Penyampaian Laporan Keuangan Berkala.

Peraturan tersebut mengisyaratkan secara hukum bahwa adanya kepatuhan setiap perilaku individu maupun organisasi yang terlibat di pasar modal Indonesia untuk menyampaikan laporan keuangan tahunan perusahaan secara tepat waktu ke Bapepam. Hal ini sesuai dengan teori kepatuhan (compliance theory). Teori kepatuhan mendorong perusahaan untuk berusaha menyampaikan laporan keuangan secara tepat waktu karena selain merupakan kewajiban perusahaan untuk menyampaikan laporan keuangan tepat waktu, juga akan bermanfaat bagi para pengguna laporan keuangan (Sulistyo, 2010).

Profitabilitas adalah kemampuan suatu perusahaan untuk menghasilkan keuntungan atau laba dalam suatu periode tertentu. Wiagustini, (2014:86) menjelaskan bahwa profitabilitas menunjukan kemampuan perusahaan memperoleh laba atau ukuran efektivitas pengelolaan manajemen perusahaan. Semakin tinggi profitabilitas sebuah perusahaan maka kinerja perusahaan dalam mengelola asset dan menghasilkan laba akan semakin meningkat (Joened dan Damayanthi, 2016). Na'im dalam penelitian Subekti dan Widiyanti (2004) menyatakan bahwa tingkat profitabilitas yang lebih rendah akan memacu kemunduran publikasi laporan keuangan auditan. Berdasarkan teori sinyal, profitabilitas yang tinggi merupakan sinyal yang baik dan dapat menjadi berita baik, sehingga perusahaan cenderung untuk melaporkan laporan keuangannya secara lebih cepat kepada pihak-pihak yang berkepentingan (Listiana, 2012:11). 
I Wayan Winarta dan I Nyoman Wijana Asmara Putra. Pengaruh...

Dyer dan McHugh, (1975) menjelaskan bahwa perusahaan yang memperoleh laba yang baik akan tepat waktu dalam menyampaikan laporan keuangannya dan sebaliknya jika suatu perusahaan mengalami kerugian, perusahaan cenderung akan menunda penerbitan laporan keuangan. Perusahaan yang memiliki profitabilitas tinggi dapat dikatakan bahwa laporan keuangannya mengandung berita baik (good news) dan perusahaan yang mempunyai berita baik akan cenderung melakukan publikasi laporan keuangannya tepat waktu (Andayani, 2015). Penelitian mengenai hubungan profitabilitas dan ketepatwaktuan publikasi laporan keuangan yang dilakukan oleh Putra dan Ramantha, (2015), Mahendra dan Putra, (2014) serta Sanjaya dan Wirawati, (2016), menunjukkan bukti empiris bahwa profitabilitas secara signifikan berpengaruh positif terhadap ketepatwaktuan publikasi laporan keuangan. Berdasarkan uraian tersebut maka dapat dirumuskan hipotesis sebagai berikut.

$\mathrm{H}_{1}$ : Profitabilitas berpengaruh positif pada ketepatwaktuan publikasi laporan keuangan.

Solvabilitas digunakan untuk mengukur kemampuan perusahaan dalam membayar semua utangnya (baik utang jangka pendek maupun utang jangka panjang) dengan menggunakan harta perusahaan. Solvabilitas yang buruk merupakan bad news bagi perusahaan karena menunjukan adanya risiko keuangan yang tinggi akibat kesulitan dalam membayar utang yang besar (Almilia dan Setiady, 2006). Oleh karena itu, perusahaan dengan kondisi seperti ini cenderung akan menunda penerbitan laporan keuangannya. Waktu penundaan tersebut digunakan untuk menekan tingkat solvabilitas serendah mungkin, sehingga 
ISSN: 2302-8556

E-Jurnal Akuntansi Universitas Udayana

Vol.25.2.November (2018): 1534-1564

mengakibatkan rentang waktu penyajian laporan keuangan menjadi lebih lama dan perusahaan akan terlambat dalam mempublikasikan laporan keuangan.

Perusahaan yang memiliki tingkat solvabilitas yang tinggi menandakan bahwa suatu perusahaan sangat bergantung pada utang dari pihak luar untuk membiayai seluruh aktifitasnnya (Devi dan Suaryana, 2016). Hal ini menandakan bahwa perusahaan yang memiliki solvabilitas yang buruk dapat dikatakan bahwa laporan keuangnnya mengandung berita buruk (bad news), dan mempunyai risiko keuangan yang tinggi. Rachmawati, (2008) dalam penelitiannya tentang pengaruh faktor eksternal daninternal perusahaan terhadap audit delay \& timeliness menyatakan bahwa solvabilitas berpengaruh signifikan negatif terhadap ketepatwaktuan publikasi laporan keuangan. Penelitian tersebut juga didukung oleh (Pande dan Mertha, 2016) yang menyatakan bahwa solvabilitas berpengaruh positif terhadap keterlambatan penyampaian laporan keuangan, hal tersebut berarti bahwa solvabilitas berpengaruh negatif pada ketepatwaktuan publikasi laporan keuangan. Berdasarkan uraian tersebut, maka dapat dirumuskan hipotesis sebagai berikut.

$\mathrm{H}_{2}$ : Solvabilitas berpengaruh negatif terhadap ketepatwaktuan publikasi laporan keuangan

Ukuran perusahaan adalah suatu skala yang dapat mengklasifikasikan perusahaan menjadi perusahaan besar dan kecil menurut berbagai cara seperti total aktiva dan tingkat penjualan. Perusahaan yang masuk dalam kelompok perusahaan besar akan cenderung lebih mampu dan stabil untuk menghasilkan laba dibandingkan dengan perusahaan kecil. Laba yang besar akan 
I Wayan Winarta dan I Nyoman Wijana Asmara Putra. Pengaruh...

memungkinkan perusahaan untuk menyampaikan laporan keuangannya tepat waktu, dan sebaliknya jika suatu perusahaan mengalami kerugian, perusahaan cenderung akan menunda penerbitan laporan keuangan (Dyer dan McHugh, 1975).

Pengendalian internal dari perusahaan besar lebih kuat dibanding perusahaan kecil, kontrol internal yang efektif memungkinkan kesalahan atau salah saji dalam laporankeuangan rendah. Terkait hal tersebut semakin besar ukuran perusahaan maka semakin bagus juga kontrol internal yang diterapkan sehingga bisa mendorong terjadinya peningkatan laba/profit. Hasil Penelitian (Toding dan Wirakusuma, 2013) menyatakan bahwa ukuran perusahaan berpengaruh positif terhadap ketepatwaktuan publikasi laporan keuangan. Hasil penelitian Toding didukung oleh penelitian yang dilakukan oleh Andayani (2015) yang menunjukan bahwa ukuran perusahan perusahaan berpengaruh positif pada ketepatwaktuan publikasi laporan keungan. Hal ini berarti besar kecilnya suatu perusahaan mempengaruhi cepat tidaknya laporan keuangan diselesaikan. Dengan demikian hipotesis penelitian ini adalah sebagai berikut.

$\mathrm{H}_{3}$ : Ukuran perusahaan memperkuat pengaruh profitabilitas pada ketepatwaktuan publikasi laporan keuangan.

Ukuran Perusahaan dapat menunjukan seberapa besar informasi yang terdapat didalamnya, sekaligus mencerminkan kesadaran dari pihak manajemen mengenai pentingnya informasi, baik bagi pihak eksternal maupun pihak internal perusahaan (Andayani, 2015). Perusahaan besar cenderung memerlukan dana yang lebih besar untuk menjalankan operasinya dibandingkan perusahaan kecil. 
Dana yang diperlukan tersebut bersumber dari pemilik perusahaan maupun dari pinjaman. Tingginya rasio solvabilitas baik perusahaan besar maupun kecil mengindikasikan risiko bisnis yang semakin tinggi pula, sehingga dapat menjadi sinyal bad news bagi pasar. Hal ini menyebabkan perusahaan meminta auditor untuk memperpanjang waktu audit, karena perusahaan ingin menunda penyampaian laporan keuangan yang mengandung bad news tersebut. Almilia dan Setiady, (2006) menjelaskan bahwa solvabilitas yang buruk akan mengindikasikan bad news bagi perusahaan karena akan menunjukan adanya risiko keuangan yang tinggi akibat kesulitan dalam membayar hutang yang besar. Hasil Penelitian Sanjaya dan Wirawati, (2016) menjelaskan bahwa ukuran perusahaan berpengaruh positif terhadap ketepatan waktu pelaporan keuangan. Dengan demikian hipotesis penelitian ini adalah sebagai berikut.

$\mathrm{H}_{4}$ : Ukuran perusahaan memperkuat pengaruh solvabilitas pada ketepatwaktuan publikasi laporan keuangan.

\section{METODE PENELITIAN}

Penelitian ini menggunakan pendekatan kuantitatif berbentuk penelitian asosiatif. Penelitian asosiatif yaitu penelitian yang bertujuan untuk mengetahui hubungan antara dua variabel atau lebih (Sugiyono, 2016:13) Penelitian ini membahas mengenai pengaruh profitabilitas, dan solvabilitas pada ketepatwaktuan publikasi laporan keuangan dengan ukuran perusahaan sebagai variabel pemoderasi. Adapun desain penelitian ini disajikan pada gambar berikut. 


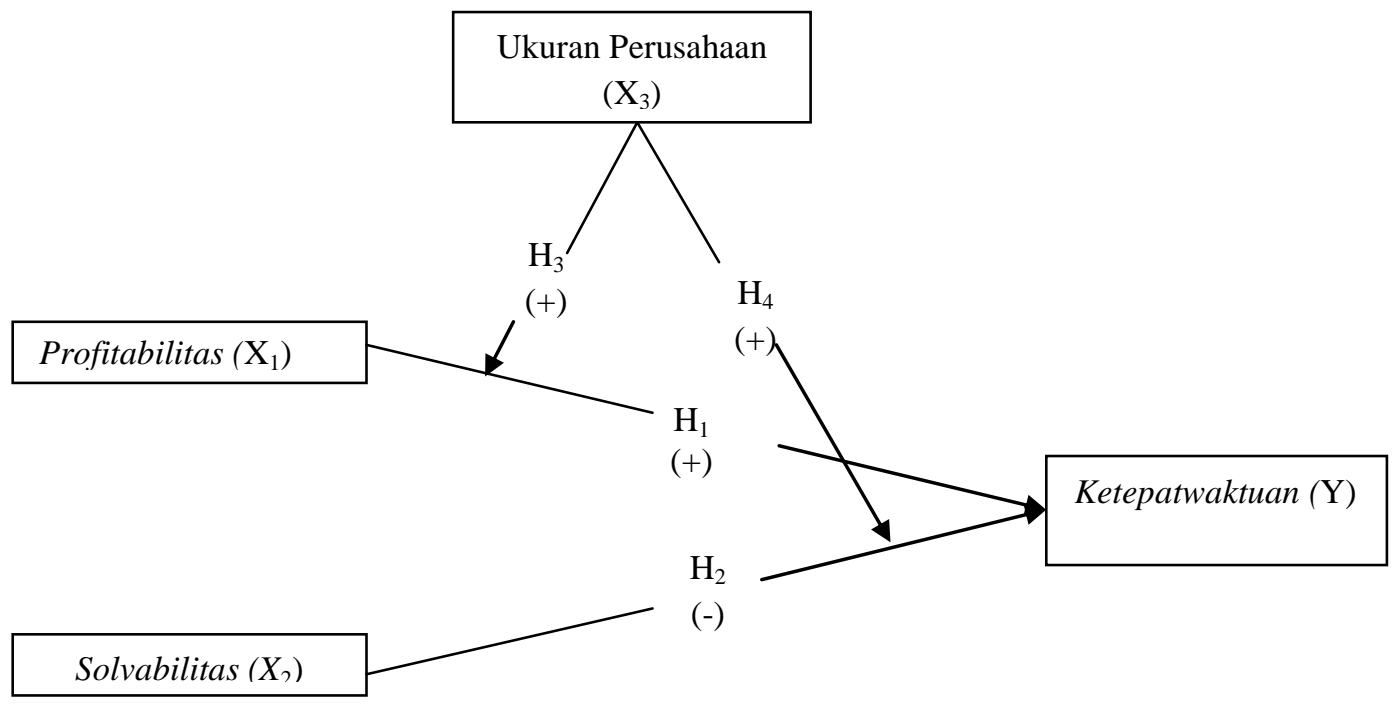

Sumber: Data diolah, 2018

Gambar 1. Desain Penelitian

Penelitian ini dilakukan di Bursa Efek Indonesia (BEI) dengan mengakses situs resmi BEI yaitu www.idx.co.id. Penelitian dilakukan pada perusahaan pertambangan yang terdaftar di BEI tahun 2014-2016. Variabel bebas (independent), yaitu variabel yang memengaruhi atau menjadi sebab perubahan atau timbulnya variabel terikat (dependent). Variabel bebas dalam penelitian ini adalah profitabilitas $\left(\mathrm{X}_{1}\right)$ dan solvabilitas. $\left(\mathrm{X}_{2}\right)$. Profitabilitas diukur dengan Return on Assets (ROA) yaitu ratio antara laba bersih setelah pajak dengan total aktiva. Semakin tinggi rasio ini maka kemampuan perusahaan utnuk menghasilkan laba akan semakin tinggi. Dengan mengetahui ROA, kita dapat menilai apakah perusahaan telah efisien dalam menggunakan aktivanya dalam kegiatan operasi untuk menghasilkan keuntungan. Solvabilitas digunakan untuk mengukur perusahaan dalam membayar semua utangnya (baik utang jangka pendek maupun utang jangka panjang) dengan harta perusahaan. Peneliti mengukur variabel solvabilitas dengan menggunakan rasio Total Debt To Total 
ISSN: 2302-8556

E-Jurnal Akuntansi Universitas Udayana

Vol.25.2.November (2018): 1534-1564

Asset (TDTA) atau total utang terhadap total aktiva (Wirakusuma dan Cindrawati, 2011).

Variabel terikat (dependent), yaitu variabel yang dipengaruhi atau yang menjadi akibat karena adanya variabel bebas (independent). Variabel terikat dalam penelitian ini adalah ketepatwaktuan publikasi laporan keuangan (Y). Ketepatwaktuan publikasi laporan keuangan adalah kualitas ketersediaan informasi pada saat yang diperlukan atau kualitas informasi yang baik dilihat dari segi waktu. Ketepatwaktuan publikasi laporan keuangan diukur dengan menggunakan variabel dummy, dimana apabila perusahaan mempublikasi laporan keuangan lewat dari akhir bulan ke-4 setelah tutup buku laporan keuangan tahunan maka perusahaan tersebut diberikan kategori 0 yang berarti terlambat. Perusahaan yang mempublikasi laporan keuangan sebelum akhir bulan ke-4 setelah tutup buku laporan keuangan tahunan maka perusahaan tersebut diberikan kategori 1 yang berarti tepat waktu.

Variabel moderating adalah variabel yang dapat memperkuat atau memperlemah hubungan antara variabel independen dengan variabel dependen. Variabel moderating dalam penelitian ini adalah Ukuran Perusahaan $\left(\mathrm{X}_{3}\right)$. Ukuran Perusahaan adalah variabel yang digunakan untuk mengukur seberapa besar atau kecilnya sampel perusahaan yang digunakan (Andayani, 2015). Pada penelitian ini, ukuran perusahaan diukur dengan menggunakan logaritma natural (Ln) dari total aset. Peneliti menggunakan nilai dari total aset sebab nilai total aset relatif tidak banyak mengalami perubahan dari tahun ke tahun, sehingga diharapkan dapat mencerminkan kondisi sebenarnya (Andayani, 2015).

Populasi yang digunakan dalam penelitian ini adalah perusahaan 
pertambangan yang terdaftar di BEI periode tahun 2014-2016. Untuk menentukan sampel dari populasi yang akan digunakan adalah teknik purposive sampling yaitu teknik penentuan sampel dengan pertimbangan atau kriteria tertentu yang disesuaikan dengan tujuan penulis (Sugiyono, 2016:78). Kriteria yang ditetapkan dalam pemilihan sampel adalah: 1) Perusahaan pertambangan yang tedaftar di BEI selama tahun 2014-2016; 2) Perusahaan pertambangan yang mempublikasikan laporan keuangan tahunan secara berturut-turut periode 20142016; 3) Perusahaan pertambangan yang memperoleh keuntungan secara berturutturut untuk periode 2014-2016.

Metode pengumpulan data yang digunakan dalam penelitian ini adalah metode observasi nonpartisipan. Dalam observasi nonpartisipan peneliti tidak terlibat langsung dan hanya sebagai pengamat independen (Sugiyono, 2016:204). Data dikumpulkan dengan cara mencatat, mengamati, serta mempelajari bukubuku, karya ilmiah berupa skripsi, jurnal akuntansi, catatan-catatan perusahaan yaitu annual report dan laporan keuangan audit yang didapat dengan mengakses situs resmi Bursa Efek Indonesia.

Jenis data dalam penelitian ini yaitu data kuantitatif dan data kualitatif. Data kuantitatif dalam penelitian ini adalah berupa laporan keuangan auditan perusahaan pertambangan yang terdaftar di Bursa Efek Indonesia tahun 20142016. Data kualitatif dalam penelitian ini berupa berupa daftar nama perusahaan pertambangan yang terdaftar di Bursa Efek Indonesia tahun 2014-2016. Sumber data penelitian ini adalah data sekunder. Data sekunder dalam penelitian 
ISSN: 2302-8556

E-Jurnal Akuntansi Universitas Udayana

Vol.25.2.November (2018): 1534-1564

ini adalah laporan keuangan perusahaan pertambangan yang terdaftar di Bursa Efek Indonesia (BEI) periode tahun 2014-2016 dengan mengunduh data tersebut melalui situs resmi Bursa Efek Indonesia, yaitu www.idx.co.id.

Pengujian terhadap hipotesis dalam penelitian ini dilakukan dengan menggunakan analisis regresi logistik dengan uji interaksi atau disebut dengan Moderasi Regression Analysis (MRA), karena variabel dependennya merupakan data kualitatif yang menggunakan variabel dummy dan terdapat variabel pemoderasi. Teknik analisis data dengan menggunakan regresi logistik tidak memerlukan uji normalitas pada variabel independennya (Ghozali, 2016:321) dan mengabaikan heteroskedastisitas (Gujarati, 2003:597) asumsi autokorelasi juga tidak dibutuhkan karena residual tidak memerlukan pengujian tersebut.

Penelitian ini juga menggunakan variabel moderasi. Variabel moderasi nantinya akan membuktikan apakah akan memperkuat atau memperlemah hubungan antara variabel independen dan variabel dependen. Cara pengujian variabel moderasi dalam penelitian ini menggunakan uji interaksi atau biasa disebut dengan Moderated Regression Analysis (MRA). Analisis regresi moderasi atau moderate regression analysis (MRA) merupakan aplikasi khususnya regresi linear berganda dimana dalam persamaan regresinya mengandung unsur interaksi (perkalian dua atau lebih variabel bebas) (Liana, 2009).

\section{HASIL DAN PEMBAHASAN}

Statistik deskriptif bertujuan untuk memberikan informasi mengenai karaktersistik variabel-variabel penelitian dari suatu data yang mencakup jumlah sampel, nilai 
rata-rata (mean), nilai maksimum, nilai minimum dan standar deviasi dari masingmasing variabel. Berdasarkan pengolahan data SPSS tentang pengujian statistik deskriftif mengenai variabel profitabilitas, solvabilitas, ketepatwaktuan publikasi laporan keungan, dan ukuran perusahaan, maka didapatkan hasil analisis yang disajikan dalam Tabel 1.

Tabel 1.

Hasil Statistik Deskriptif

\begin{tabular}{cccccc}
\hline Variabel & N & Min. & Max. & Mean & Std Deviasi \\
\hline Y & 48 &, 00 & 1,00 &, 7917 &, 41041 \\
X1 & 48 &, 0002 &, 1534 &, 059425 &, 0507326 \\
X2 & 48 &, 0057 & 1,5639 &, 441552 &, 2301318 \\
X3 & 48 & 26,6260 & 32,0992 & 29,130048 & 1,2278747 \\
X1_X3 & 48 &, 0069 & 4,6580 & 1,729533 & 1,4796064 \\
X2_X3 & 48 &, 1638 & 43,6840 & 12,814625 & 6,4437064 \\
Valid N (listwise) & 48 & & & & \\
\hline Sumber: Data diolah 2018 & & & &
\end{tabular}

Variabel ketepatwaktuan publikasi laporan keuangan (Y) memiliki nilai minimum sebesar 0 dan nilai maksimum 1 . Hal ini menunjukan variabel ketepatwaktuan merupakan variabel dummy, dimana angka 0 menunjukan perusahaan tidak tepat waktu dalam menyampaiakan laporan keuangan, sedangkan angka 1 menunjukan perusahaan tepat waktu dalam mempubikasikan laporan keuangan. Nilai rata-rata (mean) sebesar 0,7917 menunjukan bahwa terdapat lebih banyak perusahaan yang tepat waktu mempublikasikan laporan keuangan daripada yang tidak tepat waktu. Dengan nilai standar deviasi sebesar 0,41041 artinya, terjadi penyimpangan sebesar 0,41041 persen dari rata-ratanya.

Profitablitas merupakan suatu ukuran dalam persentase yang digunakan untuk menilai sejauh mana perusahaan mampu menghasilkan laba selama periode tertentu. Berdasarkan hasil uji statistik deskriptif, profitablitas memiliki nilai 
minimum sebesar 0,002 nilai maksimum sebesar 0,1534 , nilai rata-rata sebesar 0,059425 dan standar deviasi sebesar 0,0507325. Hasil ini memiliki arti bahwa persentase profitablitas pada perusahaan sampel paling rendah yaitu sebesar 0,002 yang dimiliki oleh perusahaan PT. Surya Esa Perkasa Tbk. (ESSA) pada tahun 2016. Profitabilitas pada perusahaan sampel paling tinggi yaitu sebesar 0,1534 yang dimiliki oleh PT. Samindo Resources Tbk. (MYOH) pada tahun 2015. Ratarata persentase profitablitas pada perusahaan sampel yaitu sebesar 0,059425 menunjukkan sampel perusahaan memiliki tingkat profitablitas yang rendah. Standar deviasi menunjukkan angka 0,0507326 artinya, terjadi penyimpangan sebesar 0,0507326 persen dari rata-ratanya.

Solvabilitas merupakan kemampuan perusahaan untuk memenuhi kewajiban finansialnnya baik dalam jangka pendek maupun jangka panjang atau mengukur sejauh mana perusahaan dibiayai dengan hutang. Nilai minimum solvabilitas adalah sebesar 0,0057 yang dimiliki oleh perusahaan PT. Golden Energy Mines Tbk. (GEMS) pada tahun 2014, yang menandakan bahwa dari seluruh aset PT. Golden Energy Mines Tbk. sebanyak 0,0057 persen dibiayai oleh utang. Sedangkan nilai maksimum solvabilitas adalah sebesar 1,5639 yang dimiliki oleh PT. Resourse Alam Indonesia Tbk. (KKGI) pada tahun 2015 yang menandakan bahwa dari seluruh assetperusahaan PT. Resourse Alam Indonesia Tbk. sebanyak 1,5639 persen dibiayai oleh utang. Rata-rata variabel solvabilitas adalah sebesar 0,441552 dengan standar deviasi sebesar 0,2301318 yang berarti 
dari seluruh asset yang dimiliki seluruh perusahaan pertambangan, rata-rata yang dibiayi oleh utang adalah sebesar 0,441552 persen.

Ukuran perusahaan menggambarkan besar kecilnya suatu perusahaan. Berdasarkan hasil uji deskriptif, Nilai minimum ukuran perusahaan adalah sebesar 26,6260 yang dimiliki oleh perusahaan PT. Citatah Tbk. (CTTH) pada tahun 2014, Sedangkan nilai maksimum ukuran perusahaan adalah sebesar 32,0992 yang dimiliki oleh perusahaan PT. Adaro Energy Tbk. (ADRO) pada tahun 2016 Rata-rata variabel ukuran perusahaan adalah sebesar 29,130048 dengan standar deviasi sebesar 1,2278747 artinya, terjadi penyimpangan sebesar 1,2278747 persen dari rata-ratanya.

Variabel profitabilitas $\mathrm{X}_{1}$ menunjukan nilai koefesien regresi positif sebesar 2411,260 dengan tingkat signifikansi sebesar 0,043 lebih kecil dari $\alpha$ 0,05 (5 persen). Berdasarkan hal tersebut dapat dikatakan bahwa variabel profitabilitas berpengaruh positif signifikan pada ketepatwaktuan publikasi laporan keuangan atau dengan kata lain $\mathrm{H}_{1}$ diterima.

Pengujian regresi logistik profitabilitas pada ketepatwaktuan publikasi laporan keuangan, menunjukkan nilai koefesien positif sebesar 2411,260 dengan tingkat signifikansi sebesar 0,043 yang lebih kecil dari $\alpha=5 \%$. Dengan demikian dapat dikatakan bahwa profitabilitas berpengaruh positif terhadap ketepatwaktuan publikasi laporan keuangan perusahaan pertambangan di Bursa Efek Indonesia periode 2014-2016. Semakin besar profitabilitas mengakibatkan perusahaan semakin cepat dalam menyampaikan laporan keuangan tahunan. Hasil penelitian 
ini mendukung penelitian yang dilakukan oleh Mahendra dan Putra, (2014), Putra dan Ramantha, (2015), Sanjaya dan Wirawati, (2016), serta Ferdina dan Wirama, (2017) yang menyatakan bahwa profitabilitas berpengaruh positif terhadap ketepatwaktuan publikasi laporan keuangan. Namun berbeda dengan hasil penelitian oleh Devi dan Suaryana, (2016), dan Saputra dan Ramantha, (2017) bahwa profitabilitas tidak memiliki pengaruh pada ketepatwaktuan publikasi laporan keuangan.

Hasil penelitian ini sesuai dengan hipotesis penelitian, ini terjadi dikarenakan semakin tinggi profitabilitas suatu perusahaan maka laporan keuangan yang dihasilkan perusahaan tersebut mengandung berita baik (good news), ini menandakan kemampuan perusahaan yang laporannya berisikan berita baik dan cenderung segera mungkin lebih tepat waktu dalam menyampaikan laporan keuangannya ke pasar modal sehingga berita ini dapat segera diterima oleh para pengguna informasi laporan keuangan. Sebaliknya, perusahaaan akan cenderung untuk menunda publikasi laporan keuangan apabila profitabilitas perusahaan lebih kecil (bad news) dibandingkan profitabilitas tahun sebelumnya.

Variabel solvabilitas $\left(\mathrm{X}_{2}\right)$ menunjukan nilai koefesien regresi negatif sebesar -67,650 dengan signifikansi sebesar 0,645 lebih besar $\alpha$ 0,05 (5 persen). Koefesien regresi yang bernilai negatif dan signifikansi lebih besar dari $\alpha 0,05$ (5 persen). Berdasarkan hal tersebut dapat dikatakan bahwa variabel solvabilitas tidak berpengaruh pada ketepatwaktuan publikasi laporan keuangan. Berdasarkan hal tersebut baik solvabilitas yang tinggi tidak menjamin perusahaan tersebut 
I Wayan Winarta dan I Nyoman Wijana Asmara Putra. Pengaruh...

tidak tepat waktu, begitu juga sebaliknya. Berdasarkan hal tersebut, maka $\mathrm{H}_{2}$ ditolak.

Hasil uji hipotesis pengaruh solvabilitas pada ketepatwaktuan publikasi laporan keuangan menunjukan nilai koefisien regresi sebesar $-67,650$ dengan signifikansi sebesar 0,645 lebih besar $\alpha$ 0,05 (5 persen), atau dengan kata lain, variabel solvabilitas tidak berpengaruh pada ketepatwaktuan publikasi laporan keuangan. Berdasarkan hal tersebut menunjukan bahwa tinggi atau rendahnya solvabilitas tidak memiliki pengaruh pada ketepatwaktuan publikasi laporan keuangan. Perusahaan yang solvabilitasnya tinggi atau rendah sama-sama ingin menyampaikan laporan keuangannya tepat waktu tanpa melihat solvabilitasnya.

Hasil penelitian ini searah dengan penelitian Devi dan Suaryana, (2016) serta penelitian Dewi dan Pamudji (2013) yang membuktikan bahwa solvabilitas tidak memiliki pengaruh pada ketepatwaktuan publikasi laporan keuangan. Solvabilitas yang rendah tidak menjamin perusahaan tersebut akan tepat waktu dalam mempublikasikan laporan keuangannya. Sebaliknya, solvabilitas yang tinggi tidak menjamin pula perusahaan tersebut akan terlambat dalam penyampaian laporan keuangan perusahaan tersebut.

Interaksi antara variabel profitabilitas $\left(\mathrm{X}_{1}\right)$ dengan variabel ukuran perusahaan $\left(\mathrm{X}_{3}\right)$ menunjukan nilai koefesien regresi negatif sebesar $-78,772$ dengan signifikansi sebesar 0,045 lebih kecil dari $\alpha 0,05$ (5 persen) yang menandakan bahwa ukuran perusahaan mampu memperlemah pengaruh profitabilitas pada ketepatwaktuan publikasi laporan keuangan, yang berarti 
ISSN: 2302-8556

E-Jurnal Akuntansi Universitas Udayana

Vol.25.2.November (2018): 1534-1564

bahwa perusahaan yang besar dengan profitabilitas yang tinggi belum tentu akan mempublikasikan laporan keuangannya tepat waktu karena perusahaan yang besar cenderung banyak menemui komplik unutk menyampaiakan labanya, maka dari itu akan memanipulasi laba agar perusahaan tersebut memberikan sinyal kepada investor bahwa tiap tahunnya mengalami peningkatan laba, dan hal tersebut memerlukan waktu yang lama. Sehingga dalam penelitian ini $\mathrm{H}_{3}$ ditolak.

Hasil penelitian ini menunjukan nilai koefesien sebesar -78,772 dengan signifikansi sebesar 0,45 lebih kecil dari $\alpha=5 \%$, hal ini berarti ukuran perusahaan mampu memperlemah pengaruh profitabilitas pada ketepatwaktuan publikasi laporan keuangan. Perusahaan yang besar cenderung melewati banyak fase dan memakan banyak waktu dalam pengelolan laba oleh pihak manajer, dimana melakukan intervensi atau memengaruhi dalam proses penyusunan laporan keuangan, maka dari itu perusahaan dapat menaikan atau menurunkan laba demi kepentingannya, agar stakeholder mengetahui kinerja dan kondisi perusahaan yang baik. Selain itu perusahan besar cenderung tidak tepat waktu dalam menyajikan laporan keuangannya dikarenakan perusahaan besar banyak memiliki anak cabang dan transaksi-transaksi keuangan dibanding perusahaan kecil sehingga akan memakan waktu pengauditan lebih lama.

Interaksi antara variabel solvabilitas $\left(\mathrm{X}_{2}\right)$ dengan variabel ukuran perusahaan $\left(\mathrm{X}_{3}\right)$ menunjukan nilai koefesien regresi sebesar 2,283 dengan signifikansi sebesar 0,647 lebih besar dari $\alpha$ 0,05 (5 persen), yang menandakan bahwa ukuran perusahaan tidak mampu memoderasi solvabilitas pada 
ketepatwaktuan publikasi laporan keuangan. Dalam hal ini, baik dengan solvabilitas yang tinggi atau solvabilitas yang rendah, dengan ukuran perusahaan yang besar pun perusahaan akan mengulur waktu penyampaian laporan keuangan. Ini disebabkan karena perusahaan yang memiliki solvabilitas yang tinggi maupun rendah mengandung berita buruk (bad news). Hal ini berarti $\mathrm{H}_{4}$ ditolak.

Hasil penelitian ini menujukan bahwa ukuran perusahan tidak mampu memoderasi pengaruh solvabilitas pada ketepatwaktuan publikasi laporan keuangan. Dimana hasil pengujian regresi menunjukan koefisien sebesar 2,283 dengan signifikansi sebesar 0,647 lebih besar dari $\alpha$ 0,05 (5 persen). Besar kecilnya ukuran suatu perusahaan tidak menentukan cepat atau lambatnya dalam mempublikasikan laporan keuangan baik perusahaan tersebut memiliki solvabilitas yang tinggi atau rendah. Hal ini dikarenakan perusahaan besar dan kecil, (baik yang memiliki solvabilitas tinggi dan rendah) akan berusaha menaati ataupun mematuhi peraturan yang berlaku dalam publikasi laporan keuangan, agar perusahaan tersebut tidak kehilangan kemampuannya dalam memengaruhi pengambilan keputusan investasi.

\section{SIMPULAN}

Berdasarkan hasil penelitian yang telah dilakukan, maka dapat ditarik simpulan sebagai berikut: 1) Profitabilitas berpengaruh positif pada ketepatwaktuan publikasi laporan keuangan. Hal ini karena perusahaan dengan profitabilitas yang tinggi dapat dikatakan laporan keuangan perusahaan tersebut mengandung berita yang baik (good news), maka dari itu perusahaan akan cenderung menyampaikan 
laporan keuangannya tepat waktu; 2) Solvabilitas tidak berpengaruh pada ketepatwaktuan publikasi laporan keuangan, hal ini disebabkan tinggi atau rendahnya solvabilitas suatu perusahaan tidak mempengaruhi cepat atau lambatnya menyampaikan laporan keuangan ke publik; 3) Ukuran perusahaan memoderasi pengaruh profitabilitas pada ketepatwaktuan publikasi laporan keuangan. Namun hasil koefisien regresi yang bernilai negatif yang menunjukan bahwa ukuran perusahaan memperlemah pengaruh profitabilitas pada ketepatwaktuan publikasi laporan keuangan; 4) Ukuran perusahaan tidak dapat memoderasi pengaruh solvabilitas pada ketepatwaktuan publikasi laporan keuangan. Besar kecilnya ukuran suatu perusahaan tidak menentukan cepat atau lambatnya dalam mempublikasikan laporan keuangan baik perusahaan tersebut memiliki solvabilitas yang tinggi atau rendah.

Berdasarkan hasil penelitian dan simpulan, maka saran yang dapat diberikan adalah sebagai berikut: 1) Penelitian selanjutnya diharapkan dapat memperluas objek penelitian pada sektor non pertambangan atau pada penelitian seluruh perusahaan yang terdaftar di Bursa Efek Indonesia, serta penelitian selanjutnya juga menambah rentang waktu penelitian yang lebih panjang guna mendapatkan hasil penelitian yang lebih baik; 2) Penelitian ini menunjukan nilai Nagelkerke $R$ Square yaitu sebesar 0,589 , hal ini berarti bahwa variabilitas variabel dependen yang dapat dijelaskan oleh variabilitas variabel independen dalam penelitian ini adalah sebesar 58,9 persen, sedangkan sisanya sebesar 41,1 persen dijelaskan oleh variabel-variabel lain. Penelitian selanjutnya, diharapkan 
dapat menambah variabel lain seperti financial distress, opini audit, kompleksitas perusahaan, serta faktor-faktor lain yang dapat mempengaruhi ketepatwaktuan publikasi laporan keuangan.

\section{REFERENSI}

Adebayo, P. A., and Adebiyi, W. K. 2016. Effect of Firm Characteristics on The Timeliness of Corporate Financial Reporting: Evidence From Nigerian Deposit Money Banks. International Journal of Economics, Commerce and Management, IV(3), 369-381

Akerlof, George A. 1970. The Market for Lemons : Quality Uncertainty and The Market Mechanism. Quarterly Journal of Economics, 83 (4), 488-500.

Almilia, L. S., dan Setiady, L. 2006. Faktor - Faktor Yang Mempengaruhi Penyelesaian Penyajian Laporan Keuangan Pada Perusahaan Yang Terdaftar Di BEJ, (November), 1-29.

Andayani, Luh Diah dan Made Gede Wirakusuma. 2015. Ketepatan Waktu Publikasi Laporan Keuangan Pada Perusahaan Yang Terdaftar dalam Indeks Bisnis-27 Di BEI Tahun 2010-2013. Skripsi Jurusan Akuntansi Fakultas Ekonomi dan Bisnis Universitas Udayana, Bali

Atiase, Rowland K, Linda S. Bamber and Senyo Tse. 1989. Timeliness of Financial Reporting, the Firm Size Effect, and Stock Price Reactions to Annual Earnings Announcements, 5 CONTEMP. ACCT. RES. 526,548.

Ayushabrina, Fina. 2014. Pengaruh Faktor Internal Dan Eksternal Perusahaan Terhadap Audit Report Lag: Studi Empiris pada Perusahaan Non-financial yang Terdaftar di Bursa Efek Indonesia Tahun 2012. Skripsi Sarjana Jurusan Akuntansi pada Fakultas Ekonomika dan Bisnis Universitas Diponegoro, Semarang.

Brigham, Eugene F. dan Joel F Houston, 2011. Dasar-dasar Manajemen Keuangan, Edisi 11. Jakarta: Salemba Empat.

Carslaw, C.A.P.N, and Kaplan, S.E. 1991. "An Examination of Audit Delay: Further Evidence from New Zealand". Accounting and Bussiness Research. 85 (22), 21-32 
Clatworthy, Mark A. 2010. Does Corporate Governance Influence the Timeliness of Financial Reporting? Evidence From UK Private Companies. Accounting \& Management Control Department Research Seminar.

Devi, N. L. L. S., dan Suaryana, I. G. N. A. 2016. Pengaruh Profitabilitas dan Solvabilitas Terhadap Ketepatan Waktu Dengan Kantor Akuntan Publik Sebagai Pemoderasi. E-Jurnal Akuntansi Universitas Udayana, 17(Oktober), $395-425$.

Dewi, K. M dan Pamudji, Sugeng. 2013. Analisis Faktor-Faktor Yang Mempengaruhi Ketepatan Waktu Dan Audit Delay Penyampaian Laporan. Ejournal Accounting Universitas Diponogoro, 1-66.

Diastiningsih, N. putu J., dan Tenaya, G. A. I. 2017. Spesialisasi Auditor Sebagai Pemoderasi Pengaruh Audit Tenure Dan Ukuran KAP Pada Audit Report Lag. E-Jurnal Akuntansi Universitas Udayana, 18, 1230-1258.

Dyer, J. C., and McHugh, A. J. 1975. The Timeliness of the Australian Annual Report. Journal of Accounting Research, 13(2), 204.

Ferdina, N. W. A., dan Wirama, D. G. 2017. Pengaruh Profitabilitas, Leverage, Likuiditas dan Ukuran Perusahaan pada Ketepatwaktuan Laporan Keuangan. ISSN: 2302-8556 E-Jurnal Akuntansi Universitas Udayana. 19(3), 22932318 .

Ghozali, Imam. 2016. Aplikasi Analisis Multivariative Dengan Program IBM SPSS 23. Semarang: Badan Penerbit Universitas Diponogoro

Hasniar, Firisah dan Widyatmini. 2012. Faktor-Faktor yang Mempengaruhi Ketepatan Waktu Penyampaian Laporan Keuangan (Studi Empiris pada Perusahaan Industri Barang Konsumsi yang terdaftar di BEI Periode 20072011). Jurusan Akuntansi, Fakultas Ekonomi - Universitas Gunadarma.

Joened, J. A., dan Damayanthi, I. G. A. E. 2016. Pengaruh Karakteristik Dewan Komisaris, Opini Auditor, Profitabilitas, Dan Reputasi Auditor Pada Timeliness of Financial Reporting. Ejurnal Akuntansi Universitas Udayana $14,423-450$.

Khasharmeh, H. A., and Aljifri, K. 2010. The Timeliness of Annual Reports in Bahrain and The United Arab Emirates: An Empirical Comparative Study. The International Journal of Business and Finance Research, 4(1), 51-72. 
Liana, Lie. 2009. Penggunaan MRA dengan SPSS untuk Menguji Pengaruh Variabel Moderating terhadap Hubungan antara Variabel Independen dan Variabel Dependen. Jurnal Teknologi Informasi Dinamik, 12 (2), 90-97.

Mahendra, I. B. K. ., dan Putra, I. N. W. . 2014. Pengaruh Komisaris Independen, Kepemilikan Institusional, Profitabilitas, Likuiditas, dan Ukuran Perusahaan terhadap Ketepatwaktuan Publikasi Laporan Keuangan. E-Jurnal Akuntansi Universitas Udayana, 2, 304-324.

Oladipupo, AO and Izedomi, FIO. 2013. Relative Contributions of Audit and Management Delays in Corporate Financial Reporting: Empirical Evidence from Nigeria. International Journal of Business and Social Science. 4 (10), 199-204.

Putra, I. G. A. P., dan Ramantha, I. W. 2015. Pengaruh Profitabilitas, Umur Perusahaan, Kepemilikan Institusional, Komisaris Independen, Dan Komite Audit Pada Ketepatwaktuan Publikasi Laporan Keuangan Tahunan. E-Jurnal Akuntansi Universitas Udayana, 1, 199-213.

Putri, N. L. L. L. T., dan Putra, I. N. W. A. 2018. Pengaruh Komisaris Independen, Kepemilikan Institusional, Profitabilitas, Dan audit Tenure Pada Ketepatwaktuan Publikasi Laporan Keuangan Tahunan. E-Jurnal Akuntansi Universitas Udayana ( Unud ), Bali , 23, 761-786.

Rachmawati, S. 2008. Pengaruh Faktor Internal dan Eksternal Perusahaan Terhadap Audit Delay dan Timeliness. Jurnal Akuntansi Dan Keuangan, 10 (1), 1-10.

Saleh, R., dan Susilowati, I. 2004. Studi Empiris Ketepatan Waktu Pelaporan Keuangan Perusahaan Manufaktur di Bursa Efek Jakarta. Jurnal Bisnis Strategi. 13, 66-80

Sanjaya, I. M. D. M., dan Wirawati, N. G. P. 2016. Analisis Faktor-Faktor yang Mempegaruhi Ketepatan Waktu Pelaporan Keuangan pada Perusahaan Manufaktur Yang Terdaftar di BEI. E-Jurnal Akuntansi Universitas Udayana 15.(1) 17-26.

Saputra, K. W. S., dan Ramantha, I. W. 2017. Pengaruh Profitabilitas Dan Ukuran Perusahaan Terhadap Ketepatan Waktu Pelaporan Keuangan Dengan Opini Audit Sebagai Pemoderasi. Jurnal Akuntansi Universitas Udayana , 202, 2302-8556. 
ISSN: 2302-8556

Subekti, Imam dan N.W. Widiyanti. 2014. FAktor-Faktor yang Berpengaruh Terhadap Audit Delay di Indonesia. Simposium Nasional Akuntansi VII, hal. 991-1002.

Sugiyono, Prof. Dr. 2016. Metode Penelitian Bisnis (Pendekatan Kuantitatif, Kualitatif, dan R\&D). Bandung: Alfabeta.

Sulistyo, W. A. N. 2010. Analisis Faktor-Faktor Yang Berpengaruh Terhadap Ketepatan Waktu Penyampaian Laporan Keuangan Pada Perusahaan Yang Listing Di Bursa Efek Indonesia Periode 2006-2008. Skripsi, 1-100.

Toding, M., dan Wirakusuma, M. G. 2013. Faktor-Faktor Yang Memengaruhi Ketepatwaktuan Penyampaian Laporan Keuangan. Jurnal Akuntansi Universitas Udayana, 33, 2302-8556.

Wiagustini, Ni Luh Putu. 2014. Manajemen Keuangan. Denpasar: Udayana University Press.

Wijayanthi, Putu Krisna dan Ketut Budiartha. 2016. Financial Distress Sebagai Pemoderasi Pengaruh Opini Audit Going Concern Pada Ketepatwaktuan Publikasi Laporan Keuangan. Ejurnal Akuntansi Universitas Udayana, 17 (2), 1283-1310.

Wirakusuma, M. G., dan Cindrawati, P. M. (2010). Pengaruh Profitabilitas, Solvabilitas, Reputasi Auditor, Ukuran Perusahaan, Kandungan Laba, Dan Jenis Industri Pada Ketidaktepatwaktuan Publikasi Laporan Keuangan Di Pt Bursa Efek Indonesia Periode 2007 - 2009. Jurusan Akuntansi Fakultas Ekonomi Universitas Udayana, 1-27. 